\title{
, nat \\ Of African Descent? Blackness and the Concept of Origins in Cultural Perspective
}

\author{
Sarah Abel ${ }^{(1)}$ \\ Faculty of Social and Human Sciences, University of Iceland, 101 Reykjavík, Iceland; sabel@hi.is \\ Received: 22 January 2018; Accepted: 28 February 2018; Published: 5 March 2018
}

\begin{abstract}
Over the past decade, the DNA ancestry-testing industry-based largely in the United States-has experienced a huge upsurge in popularity, thanks partly to rapidly developing technologies and the falling prices of products. Meanwhile, the notion of "genetic genealogy" has been strongly endorsed by popular television documentary shows in the US, particularly vis-à-vis African-American roots-seekers-for whom these products are offered as a means to discover one's ancestral "ethnic" origins, thereby "reversing the Middle Passage." Yet personalized DNA ancestry tests have not had the same reception among people of African descent in other societies that were historically affected by slavery. This paper outlines and contextualizes these divergent responses by examining and comparing the cultural and political meanings that are attached to notions of origin, as well as the way that Blackness has been defined and articulated, in three different settings: the United States, France and Brazil.
\end{abstract}

Keywords: DNA ancestry testing; genetic genealogy; Blackness; origins; ethnicity; race; Brazil; United States; France

\section{Introduction}

Virtually since the emergence of the first genetic ancestry testing companies in the early 2000s, personalized DNA-testing products have been presented in the United States as tools that hold a particular significance for the descendants of enslaved Africans, whose cultures and kin structures were systematically suppressed and ruptured by the dehumanizing mechanisms of chattel slavery. In Alex Haley's best-selling 1976 novel Roots, it was the moment of the author's "return" to the alleged birthplace of his ancestor Kunta Kinte in the Gambia that constituted the story's emotional climax, symbolizing his ultimate triumph over countless attempts to rid his ancestors of knowledge of their origins and identities-a feat made possible by the analysis of linguistic elements passed down through his family folklore. From the early 2000s, certain DNA ancestry-testing companies and their advocates began to propose genetics as an alternative to Haley's genealogical approach: for instance, one of the earliest DNA ancestry-testing companies, African Ancestry, claimed to specialize in matching test-takers to one or more African ethnic groups and countries of origin, based on analyses of their Y-chromosome (Y-Chr) or mitochondrial DNA (mtDNA). These techniques were later featured on the 2006 PBS documentary African American Lives, presented by Henry Louis Gates, Jr., the charismatic Harvard professor of African-American literature, who heralded DNA testing as a means for all African Americans to emulate Haley's achievement and, "symbolically at least, to reverse the Middle Passage" (Gates 2009, p. 10).

Although the idea of using DNA ancestry-testing technologies to claim personal links to particular geographic regions or ethnic categories initially provoked stern criticisms from academic communities (e.g., Brodwin 2002; Ely et al. 2006; Bolnick et al. 2007), in recent years disputes about the tests' scientific limitations and ethical implications have somewhat subsided, as a new generation of low-priced, high-resolution genotyping tests has swept the market, receiving further endorsement from prominent 
African-American figures. For instance, in 2016, the channel HISTORY teamed up with the DNA-testing company 23andMe to offer genetic ancestry tests to the cast of a new television reboot of Roots. Among them was LeVar Burton, who played the role of Kunta Kinte in the original 1977 TV production of the show, and who co-produced its remake. Describing his reaction to his DNA results, Burton stated:

I've always felt like there's a piece of me missing; I'm sure a lot of Black people in this country have that same feeling: that who I am did not just begin here, that I'm part of a lineage that goes back much further than that-and to have the proof of that in my hands is ... it's powerful. That gives me for the first time in my life a sense of actual belonging. ${ }^{1}$

African Americans are far from the only users of DNA ancestry tests; indeed, data released by two of the largest ancestry-testing companies in the United States seem to indicate that the greatest proportion of their customers are Euro-Americans or Europeans. ${ }^{2}$ Yet, African Americans—or more broadly the African diaspora-have frequently been identified by developers and vendors of DNA ancestry tests as a special interest group for whom personalized DNA ancestry results can hold a particular significance-an idea that has aroused both excitement and concerns regarding the impacts of their commercialization upon these communities (Rotimi 2003; Winston and Kittles 2005). According to Alondra Nelson's analysis (Nelson 2016), the concept of using genetic analyses to investigate personal African-American genealogies originated in the work of African-American "activist scientists" who, in the 1990s, proposed these techniques as a means of shedding light on the geographic and ethnic origins of the remains of enslaved individuals uncovered at the site of an historical African burial ground (La Roche and Blakey 1997; Mack and Blakey 2004). This approach was later used as a basis for the personalized DNA ancestry tests that began to be sold in 2003 by the company African Ancestry-the brainchild of geneticist Rick Kittles and entrepreneur Gina Paige, who have been extremely prominent in endorsing their products as a means for Black Americans to reclaim "ancestral" African ethnic identities. Thanks to these and other figures of scientific and cultural influence, DNA ancestry testing has become largely regarded as a useful genealogical tool and a positive aid for identity construction for African Americans-a process that has not necessarily been replicated by other minority groups in the US (e.g., Brodwin 2005; TallBear 2013; c.f. Abu El-Haj 2012).

To date, the United States has been one of the most important global producers and exporters of personalized DNA ancestry tests, with large companies such as AncestryDNA (a subsidiary of Ancestry.com), 23andMe, Family Tree DNA, and the Genographic Project making their products available to customers outside the US for a number of years now. The intersection of DNA ancestry with processes of personal identity construction and conceptions of race and ethnicity has been discussed at some length in social science studies focusing on cases from the United States (TallBear 2003; Palmié 2007; Nelson 2008a, 2008b, 2016; Roberts 2011; Panofsky and Donovan 2017).

Far fewer studies have, so far, examined how these technologies, and the knowledge they produce, have been received and mobilized by users outside the US (Tamarkin 2014)—or compared how the production, branding and interpretations of genetic ancestry data vary among national contexts (Neto and Santos 2011; Pálsson 2012). Nevertheless, a common finding among the works of scholars who have dealt with these questions has been that African genomic ancestry is not always ascribed the same personal or political significance-particularly in non-Anglophone settings-as in the United States (Santos and Maio 2005; Benn Torres 2014; Kent et al. 2014).

This paper aims to contribute to this area of discussion by offering a comparison of the varying responses to DNA ancestry testing among African-descendant groups in three national contexts: the US, France and Brazil. These cases have been chosen because they highlight differing practices

1 See "Know Your Roots: LeVar Burton and Malachi Kirby I History, 2016." Video clip published on YouTube by HISTORY, 26 May 2016. Available online: https:/ / www.youtube.com/watch?v=y_gJ9inlFG0 (accessed on 19 January 2018).

2 See Byrnes (2013), and “23andMe Research Portal Platform," published by 23andMe, 29 October 2014. Available online: https: // objects.23andme.com/res/permalink/pdf/ashg/10292014_23andMeResearchPortal.pdf (accessed on 25 February 2018). 
and perspectives, not only with regards to genetic technologies, but more generally in relation to root-seeking as a political act, and in the following analysis I attempt to untangle the interweaving of historical dynamics and sociopolitical stakes that account, to some extent, for these divergences. My account draws on data gathered through a comparative anthropological study conducted between 2012 and 2015, which focused on the scientific construction of personalized genomic ancestry and the ways in which these data are currently being utilized in relation to the development and negotiation of Black identities. ${ }^{3}$ For the cases of the US and Brazil, my analysis is grounded in a cohort of more than 130 interviews with DNA test-takers, genealogists, activists, academic and commercial geneticists, as well as public advocates and critics of genetic ancestry testing. These data are supported and contextualized by ethnographic notes taken during trips to genetic-genealogy conferences and visits to an African-American genealogy group; netnographic analyses of social media communities and blog sites involved in sharing and discussing personalized DNA ancestry data; as well as close readings of prominent media productions (e.g., documentary films and special magazine features) that have been used to present genealogical research and genetic testing to the public, along with the reactions provoked by these features among social networks and in the press. For the case of France, my account is based on primary and secondary texts written by members of the group CM98 and social scientists who have worked with the collective, and supplemented by my own observations during my time spent working as a researcher at the International Center for Research on Slaveries (Centre international de recherches sur les esclavages-CIRESC) in Paris from 2012 to 2016.

Taking inspiration from the title of this special issue, "Sankofa; or 'Go Back and Fetch It,"' the following account focuses on how notions of roots and ancestry have been conceptualized in these three cultural contexts, in relation to debates around the usage of DNA ancestry tests as a mode of producing knowledge about personal and collective Black genealogies. In particular, I look at where, when, and with whom these genealogies are made to originate, examining the political work these symbolic roots are doing, and how they attend to particular cultural conventions and identity projects in each national setting. In order to achieve this, I consider, in each case, how nation-building myths, historical doctrines regarding definitions of racial Blackness, and hegemonic policies aimed at incorporating Black populations into national bodies since the abolitions of slavery, have informed readings of DNA ancestry data and led to divergent interpretations of their relevance to personal and collective histories. Following Geertz's (Geertz 2000) interpretative approach to cultural analysis, I seek to ground these symbolic regimes in contemporary social events and public discourses, foregrounding the roles of particular groups and public figures who have distinguished themselves as interpreters and "artisans" of genetic and/or genealogical knowledge in their own countries; outlining their own inspirations and political visions; and, where possible, assessing their influence in terms of shaping and inspiring genealogical practices "on the ground."

My account begins with an examination of the United States-a setting where family history practices and uses of DNA ancestry tests are notoriously widespread. In her recent book The Social Life of DNA, Alondra Nelson (Nelson 2016) has described in detail the pan-Africanist, ethnicity-oriented model of DNA testing endorsed by the company African Ancestry and its advocates. Here, I aim to complement Nelson's analysis by focusing on an alternative genetic-genealogical model put forward by Henry Louis Gates, Jr., who likewise emphasizes the revelation of ethnic identities as a key goal of DNA ancestry testing for African Americans, but ultimately orients these practices towards a hegemonic, multicultural paradigm of identity. This is followed by a discussion of the contrasting case of a French Antillean collective who are using genealogical research as a means of visibilizing

3 This study formed the basis for my doctoral dissertation, "'The Power of Knowing ... ' On the Scientific Construction and Social Uses of DNA Ancestry Tests in Two Post-Slavery Societies: Brazil and the USA," defended at the École des hautes études en sciences sociales in Paris in 2016. The research was part of the EUROTAST project, a Marie Skłodowska-Curie Actions Initial Training Network that ran from 2011-2015 and studied the history and legacies of the transatlantic trade in enslaved Africans using multi- and interdisciplinary methods. See http:/ / eurotast.eu/ (accessed on 25 February 2018). 
the identities and histories of their enslaved ancestors within France's national history, but whose collective notion of origin is not situated in Africa. Finally, I present some examples from Brazil, whose national ideology of mixture is seen as constantly threatening to subsume the attempts of activist groups to create a distinct political identity based on various interpretations of Blackness. Using these cases, I aim to offer a more complex picture of Black genealogical practices across the Americas, problematizing the message that has been widely encouraged by US-based genetic-testing companies and their promoters, that claiming an African ethnic or national identity is the ultimate goal for descendants of enslaved Africans to be able to symbolically "reverse the Middle Passage."

\section{The Importance of Roots in the United States}

It has become a truism to remark that the United States is a nation obsessed by genealogy. Indeed, as Weil (2013) has observed, genealogical practices have a long history in the country, stretching back to colonial times. However, while the private compilation of family trees and public participation in antiquarian and genealogical societies were pastimes that were historically reserved for elite Whites, since the second half of the twentieth century the field of genealogy has undergone a democratizing effect. Today, taking an interest in one's origins and family heritage is not only looked upon as a healthy and desirable activity for all citizens in America's multicultural society, but researching one's family history has become more accessible and feasible than ever before, thanks to a proliferation of online genealogy databases.

Genealogical activities are even fostered from a young age; family tree projects, for instance, are a staple of show-and-tell lessons for American schoolchildren. Although these activities are typically intended to instill young students with a sense of pride in their unique family story, they can also bring to light discrepancies in the accumulated family history knowledge of classmates of different social and ethnic backgrounds. During a series of interviews I conducted in 2014 with Americans who had taken DNA ancestry tests, the topic of the school family history project was mentioned by various African-American test-takers as a moment when they first felt aware of not knowing their family origins, as other classmates did. Jarreau, for instance, recalled being at middle school in New Jersey in the mid-1990s, and being given the task of coloring in the countries from which his ancestors originated on a map of the globe. Enlisting the aid of his grandmother, he colored in several European countries: England, Scotland, Ireland, Italy. When it came to the family's origins in Africa, however, Jarreau's grandmother told him that they would never know where exactly they came from, saying it was "almost impossible to tell." His schoolteacher, meanwhile, instructed him to color the entire continent—a solution, Jarreau remarked, that "didn't sit well with me." As if to make matters worse, Jarreau remembered that the only other two Black students in his class were the children of Nigerian immigrants, and seemed to have no issue filling in their own ancestry maps. ${ }^{4}$

The perceived importance for US citizens of being able to name an "ethnicity" or "culture" of origin is today underpinned by the convention of the hyphenated American identity. The term "hyphenated American" was originally coined by American politicians in the early twentieth century, when it was used pejoratively to refer to recently-disembarked European immigrants who were suspected of divided loyalties in the fraught political context of the First World War (Higham 1975, p. 198). During the second half of the century, however, the idea of the "hyphen nation" came to be seen as a touchstone for the new concept of a multicultural American society. According to Matthew Frye Jacobson, this change was catalyzed by the civil rights movement, which "introduced a new and contagious idiom of group identity and group rights on the American scene" (Frye Jacobson 2006, p. 19). In Frye Jacobson's analysis, this new paradigm allowed the descendants of recent European immigrants to reject the norm of a White racial identity to which their parents and grandparents had aspired-which, in the contemporary political context, was increasingly 
associated with the historical violence inflicted by White colonists upon enslaved Africans and Native Americans-instead reviving ethnic identity categories as rallying points for their own agendas of collective political action.

At the time, some liberal social commentators-like the theologian and philosopher Michael Novak, author of the book The Rise of the Unmeltable Ethnics (1973)—described this ethnic turn as a form of historical consciousness, which implied a healthy acceptance of the cultural diversity coloring each American family, thanks to their unique ethnic background. According to Novak, all Americans "have" an ethnicity, which he defined as "a cast of mind, a set of cues, an historical memory, a set of approved stories to live out" (Novak 1973, p. xvii). The exception, in Novak's view, consisted of groups like Black Americans and Chicanos, who, as the result of generations of oppression, had "suffered historical amnesia; consciously, at least, they are rootless, without cultural memory, loyal to no tradition or project" (Novak 1973, p. xvii). This assessment chimed with the theories of certain prominent sociologists, who diagnosed the apparent anomie and familial disorganization among poor Black communities as consequences of the systematic eradication of African cultural traditions through slavery (Du Bois et al. 1996; Frazier 1939; Moynihan 1965).

The publication of Alex Haley's Roots in 1976 and the novel's subsequent TV adaptation, aired over the course of a week in February 1977, seemed to offer a stark rebuttal to this idea. In his book, Haley detailed how a combination of traditional genealogical research and linguistic analyses of African terms passed down through his family's oral folklore had permitted him to trace his ancestral origins to a small village in the Gambia, where he heard the history of his people recounted by a local griot, before being symbolically welcomed "back" in the community by a ceremony called "the laying on of hands" (Haley 2007, pp. 875-77). The author's representation of the cathartic power to be unleashed by uncovering the traumas and triumphs of one's enslaved ancestors, and ultimately by reclaiming a link to an African cultural tradition and kinship community, inspired a generation of Black Americans to begin researching their own family histories. As Ashraf Rushdy has suggested, Roots appeared to offer a model for "finding the historical sources to tell the story of the family from slavery to freedom, and responding to the shame and secrecy of that part of the American past" (Rushdy 2001, pp. 15-16). Although Haley was far from the first person to condone the idea of going "back to Africa" for descendants of slaves-a slogan that had been championed by various Black political and cultural movements since the mid-nineteenth century (Schramm 2010)-he nonetheless popularized the notion of connecting with a particular African country through the (re)construction of a personal genealogical link. Somewhat ironically, in light of the criticisms that were later directed at the rigor and historical accuracy of his own genealogical research, ${ }^{5}$ Haley's narrative planted the notion of the African "root" as a unique and historically authentic lineage waiting to be uncovered-an ideal that has come to eclipse other collective projects of "return," based on political or religious enterprises and typically oriented towards nations like Liberia, Ghana and Ethiopia (Guedj 2009).

It is important to note that the genealogical fervor whipped up by Roots did not only affect Black communities in the United States. For instance, the National Archives reported that following the broadcast of the TV miniseries (whose final episode still ranks among the top five most-watched television episodes in US history (Lynch 2017)), requests to use their research facility increased by $40 \%$ (Rushdy 2001, p. 15). In the following decades, the growing public interest in genealogy was fed by the emergence of a plethora of organizations, services, and databases, focused on

5 Two genealogists, Elizabeth Shown Mills and Mills (1981), studied documentary evidence regarding the family lineage depicted by Haley in Roots, finding numerous factual errors or unsubstantiated claims relating to the pre-Civil War part of the account, including Haley's identification of the slave Toby as his ancestor Kunta Kinte (the former was found by the genealogists to have been living in Virginia for at least five years before the latter was supposed to have arrived there on the ship Lord Ligonier). Meanwhile, journalists and historians who had visited and worked in the Gambia raised suspicions that the griot who provided the crucial details of Haley's genealogical link to the community of Juffure may have invented or embellished aspects of the oral history precisely in order to confirm Haley's desired connection to Kunta Kinte (Wright 1981; Mills and Mills 1984). 
improving public access to records, as well as facilitating communication among family historians. The country's first genealogy-based businesses emerged in the 1980s, producing user handbooks and magazines on genealogical research, and offering personalized genealogy services to subscribers. In the 1990s, some of these companies began migrating their services to the Internet, setting up online databases that subscribers could access from the comfort of their own homes, as well as Internet forums and message boards for genealogists to exchange research advice (Garrett 2010, pp. 16-27). In 1999, the Church of the Latter Day Saints launched a free online database called FamilySearch.org, which initially offered access to some 400 million names from among the Church's collection of around two billion genealogical records. ${ }^{6}$ The site received around two million visits on the first day it went live, reportedly placing it among the top 80 most-frequented places on the web (Moulton 1999), and setting a precedent for the continuing growth of online genealogy websites into the 2000s.

The emergence of the first DNA ancestry-testing companies in the early 2000s can be seen as an extension of this trend of increasing technologization in the field of genealogy. Many of the early businesses were founded by scientists from the field of anthropological genetics, who presented their products as a way for customers to connect through their own "deep ancestry" to the ancient prehistory of human migrations around the world, using uniparental (mtDNA and Y-Chr) analyses. In the past decade, however, the DNA ancestry-testing industry has become increasingly dominated by genealogy companies, who present personalized genomic tests as supplementary tools for studying recent family histories. These businesses have taken advantage of the falling costs of new high-throughput genotyping technologies, offering low-cost products (priced at roughly $\$ 99$ per test), including features such as genetic "relative-matching" tools, and interfaces allowing customers to link their DNA results to online family trees. Undoubtedly the main attraction of these tests for most customers, however, is their high-resolution admixture analyses, breaking test-takers' genomic heritage down into dozens of statistical clusters, designated as "ancestral populations" or "ethnicities." These clusters are displayed on interactive maps-perhaps reminiscent of the charts that American schoolchildren, like Jarreau, are asked to fill in every year for their family history projects-and are typically denominated using contemporary geopolitical labels, resulting in a menu of "ethnic" categories that customers can incorporate seamlessly into their hyphenated identities.

The distillation of these fine-scale "ethnic" clusters is not merely the natural outcome of technological and research progress in the field, but has also been a political goal pursued by certain industry leaders and other public figures, who have regarded DNA ancestry testing as a tool for informing personal histories and constructing ethnic identities. While Alondra Nelson (Nelson 2016) has thoroughly documented the role of the company African Ancestry in this respect (see also Abel 2016), Henry Louis Gates, Jr. has been another prominent figure within this panorama. Gates first began studying his family history at the age of nine, and admits to having had "a serious case of roots envy" since watching Roots in 1977. By his account, it was having his own DNA analyzed in the early 2000s by the company African Ancestry, who matched him genetically to Nubian people of Egypt, that inspired him to make the PBS documentary series African American Lives. ${ }^{7}$ Mirroring Haley's narrative arc, the series followed the family histories of Gates and eight other well-known African-American figures as they were traced back from the present day through slavery. The show's climax came with the revelation of the guests' African origins via DNA analysis, after which one guest, the comedian Chris Tucker, was invited to visit members of the Mbundu community in Angola, where geneticists working for the show had placed his paternal ancestral origins.

6 Since 1894, the Church's acolytes have been copying and collecting genealogical records from across Europe and North America, to aid the posthumous conversion of their ancestors to Mormonism. In the 1960s, the Church began building local branches of its central Family History Library across the United States, making microfilm copies of documents from its vast genealogical database available to members of the public (McKay 2002).

7 Interview, 5 May 2014. 
Combining genealogical and genetic approaches to family history have since become a staple of Gates' popular franchise of PBS genealogy documentaries, with his 2012 production of Finding Your Roots reaching a cumulative audience of some 16.6 million viewers. ${ }^{8}$ In these series, Gates emphasizes the anti-racist potential of DNA testing-which he portrays as deconstructing older notions of America as made up of biologically "pure" races-while also portraying genetic ancestry as a reliable tool for connecting individuals to their family's ethnic heritage, thereby fully embracing America's multicultural model of identity. As well as partnering with different DNA-testing companies for the production of these series, Gates has also taken direct action to try and influence DNA-testing companies into improving their techniques for matching customers to particular "ethnic" groups. For instance, after being informed by some of the scientists working on African American Lives that his earlier "Nubian" DNA result was probably inaccurate- a conclusion that chimed with concerns raised by other academics about the limitations of African Ancestry's methods (Rotimi 2003; Ely et al. 2006; Nelson 2016, pp. 63-65)—Gates decided to establish a new testing company, AfricanDNA, publicly declaring his aim to provide a more refined approach to tracing customers' ancestry within Africa (Winstein 2007). ${ }^{9}$ When I spoke to Gates in 2014 about AfricanDNA's objectives, he reiterated his desire to be able to offer customers a service that provided them with the name of a tribe or ethnic group of origin, stating, "that's what African Americans want." 10

In the introduction to his book In Search of Our Roots: How 19 Extraordinary African Americans Reclaimed Their Past, adapted from the two series of African American Lives, Gates described this use of DNA technologies to link African Americans to contemporary African populations as a way of symbolically "revers[ing] the Middle Passage" (Gates 2009, p. 10). In his words:

A match means that we've found someone with whom we share a common ancestor. And back in Africa, scientists have spent several decades gathering such samples from tens of thousands of Africans. So an exact match between an American's DNA and an African's DNA reveals a shared ancestor, and possibly a shared ethnic identity, that has been lost for centuries. (Gates 2009, p. 10)

As several researchers have shown through anthropological and sociological studies of DNA test-taking practices, personal impacts of genetic ancestry data upon test-takers are varied, as are the social and political uses to which individuals put this new knowledge (Nash 2008, pp. 219-63; Sommer 2012; Tamarkin 2014; Scully et al. 2016). In her detailed study of the "social life" of DNA ancestry data produced by African Ancestry, Alondra Nelson (Nelson 2016) outlined cases in which these genetic reports have been used as grounds for social transformations (e.g., undergoing naming ceremonies), as well as to underpin legal and political demands (requesting citizenship in an African "homeland"; litigating in favor of restitution for slavery) (see also Schramm 2012). Yet, like other scholars who have explored the notion of the "return" to Africa as a way of healing the scars of slavery (e.g., Hartman 2007), Nelson's account also points to the limitations of DNA testing as a means of achieving this catharsis, and even to the paradoxes that can arise from reconciliation attempts among genetically-matched Americans and Africans (see also Nelson 2008a).

8 See "PBS Series American Masters and Finding Your Roots with Henry Louis Gates, Jr., Reach Record Number of Viewers." Thirteen website, 26 July 2012. Available online: http://www.thirteen.org/13pressroom/company-news/pbsseries-american-masters-and-finding-your-roots-with-henry-louis-gates-jr-reach-record-number-of-viewers / (accessed 19 January 2018).

9 AfricanDNA was cofounded in 2008 by Gates and the company Family Tree DNA (based in Houston, Texas). The AfricanDNA website offered uniparental DNA analyses, with reports including a tailored historical interpretation of the results, linking them to the context of the transatlantic slave trade. The company has since been fully incorporated into Family Tree DNA.

10 Interview, 29 April 2014. 
Most of the DNA test-takers I interviewed had not taken such drastic steps after receiving their genetic results. Instead, many portrayed the initial value of these data in terms of being able to put a finger on a map and name a place (or places) of origin. This idea was alluded to by Jarreau when I asked him whether he felt it was important for Americans to find out about their ancestry. He replied:

For my African Americans, most definitely. The idea of Sankofa is to move forward you must look to your past. How can we come together, experience pride, share culture without knowing where we come from? We love claiming a street we grew up on, a city where we live, these locations that don't actually provide us much, but we never think about the places that actually birthed us centuries ago. It's time to move forward by looking back.

Jarreau's spontaneous reference to Sankofa—an Akan adinkra symbol, traditionally represented either as a heart or a bird with its head turned back over its body-was meant to explain the importance for African Americans, like their African ancestors before them, of knowing where they come from. For him, the site of those roots seemed self-evident: a cultural "birthplace" outside the US, which, despite being located beyond the immediate lived experiences of most Americans, he attributed a greater symbolic significance as an imagined place for individuals to "come together, experience pride, share culture." Simultaneously, contained within the above affirmation is a sense that the United States cannot be a true place of origin, particularly for Black Americans-an idea that Jarreau evoked at other points in our conversation, referring to himself before he had received his DNA results as a "displaced person" and a "lost child of the diaspora." In Jarreau's experience, being able to name his African countries of origin had allowed him to begin performing a sense of belonging to these "imagined communities" (Anderson 1991) within American society, until he could achieve his ultimate aim of visiting these countries in person. For instance, Jarreau described how he had enjoyed talking about his results to African immigrants-as a means of conveying to them his deep interest in cultivating a personal connection with the continent-as well as his pleasure at now being able to follow particular African teams in soccer tournaments, "rather than just picking a country because of a shirt color or star player."

Nonetheless, this idea of US as a site of displacement was not shared by all of the genetic test-takers with whom I spoke. One collective that stood out in particular as having a different conception of their family roots was a group of African-American genealogists who met on a weekly basis at a Family History Center (FHC) in Maryland. Almost all of the dozen or so regular members of the group had taken one or more DNA ancestry tests, mainly on the recommendations of one of their number, Bernice-who, beside being a seasoned genealogist, also hosts a weekly podcast on genealogy and history. During my visits to the FHC between February and May 2014, several members of the group offered to show me their test results online. Yet, as they logged into their genetic testing profiles, most skipped over the brightly colored ancestry maps without comment. When I inquired about these results, some admitted they had never really paid much attention to them before, stating that they were much more interested in the "relative-matching" features provided by certain companies, as a means of getting in touch with possible cousins or other living relatives who might be able to help fill in clues about their family histories. Bernice, for her part, explained that she saw these "ethnicity" results as a way to "get a feel for where I could have been from Africa. But to find the first African, I haven't got to the point where I'm digging that far, I'm still trying to start with myself and take it back as far as I can; document it, paperwise, as far as I can."11

Bernice's approach is typical of genealogical methods of root-seeking, which, according to experts in the field, should begin with the recent past and work further back, documenting kinship connections one generation at a time. As a result, some genealogists have opposed the use of genetic "ethnicity" testing as a means to locate a family lineage in Africa, arguing that this approach does not allow

11 Interview, 12 May 2014. 
test-takers to situate this link historically within the context of a conventional family tree (Oduah 2009). Indeed, as Bernice's comment indicated, most of the FHC attendees were engaged in shedding light on much more recent histories. The anecdotes told to me during those sessions rarely made mention of Africa, nor were they always focused on slavery. Rather, they dealt more often with recent mysteries, separations, and tragedies: for instance, searches for missing fathers and grandfathers; attempts to reunite two sides of a family who lost touch during the Great Migration; the case of an uncle left for dead in a hit-and-run incident in the Jim Crow south, whose killers-a family known locally for their racist ideals-were never brought to justice. Furthermore, the places that rooted these histories were not far-off countries, but houses, villages and towns in North Carolina, Virginia and Louisiana: places where parents and grandparents had lived, worked, and been buried; places these genealogists had heard described in family tales, and where their distant cousins were reputed or known to still reside.

In the closing scenes of the final episode of African American Lives, Gates announced to viewers:

As DNA databases grow, and as genealogical research techniques develop, we'll be able to find with ever more accuracy the identities of our ancestors and the roots of our family trees. As we do this, we'll not only be able to heal the wounds of the Middle Passage, but we'll be able to stake our claim ever more deeply within the American tradition. (Judd and Farrell 2006)

Gates posits DNA ancestry testing and traditional genealogical research as two perfectly complementary approaches to constructing a multicultural Black American identity: the former affording root-seekers the catharsis and cultural capital of being able to name a personal African ethnic origin; and the latter allowing them to embed themselves further within the "American tradition" of family history research. Yet in my fieldwork, I more often perceived tensions and imbalances between the two approaches. On the one hand, the steeply rising sales figures of DNA ancestry tests in the past five years are in large part accounted for by consumers with little or no experience of traditional genealogical research, many of whom regard identifying their ethnic origins as the principle benefit afforded by these tools. This idea is continually reinforced by affirmations such as the one made by LeVar Burton, that "a sense of actual belonging" (my italics) can only be achieved-in particular for Black Americans-by being linked to an imagined, pre-slavery point of origin, outside of the USA. On the other hand, the testimonies of the FHC members suggest that archival research and the gathering of oral histories pertaining even to a much more shallow timeframe can help reinforce a sense of rootedness within American society, while also helping heal the more recent (and equally deeply felt) wounds sustained by Black families in the aftermath of slavery. Nonetheless, some of the genealogists I interviewed who were regular users of the genetic "relative-matching" tools provided by DNA-testing companies complained of the paucity of family history knowledge among the "neophyte" users with whom they were matched. Some expressed concerns that the popularity of DNA "ethnicity" testing may lead to an overreliance on genetics as a "shortcut" to the root of one's family tree, causing users to neglect oral histories and other ephemeral sources of qualitative genealogical data.

In this section, I have given an account of the development of the DNA ancestry-testing industry in the United States, drawing attention to the now widespread social acceptance of these products as tools for constructing "ethnic" identities, and linking the cultural and political importance that is attributed to the idea of "knowing one's roots" back to the historical context in which Haley's influential novel emerged. Inspired by the latter, in the genetic-genealogical model of family history research proposed by Gates, the desired "root" of Black genealogies is frequently located outside the United States and just beyond the experience of slavery. This idea differs from the perspectives of many African American genealogists, who typically take a much broader view on the concept of origins, linking themselves to multiple sites inhabited by their ancestors over the course of their history in the United States. While these ideas are not incompatible per se, I have suggested that the proliferation of genetic "ethnicity" testing products may be beginning to dominate over other modes of envisioning and situating personal roots. Next, I turn to the case of a French group that has been using a combined 
genealogical project as the focal point for developing a collective cultural and political identity, but whose notion of origins has been conceived of very differently.

\section{Genealogies of Resistance}

On 23 May 1998, an estimated 40,000 people, most of them Antillean, Guyanese and Réunionnais in origin, gathered to participate in a silent march between Place de la République and Place de la Nation in Paris, on the day of the 150th anniversary of the abolition of slavery in the French colonies. According to the anthropologist Christine Chivallon (Chivallon 2014), the event constituted a landmark display of public solidarity among people identifying themselves as the descendants of France's ex-slave populations. Indeed, as Viviane Rolle-Romana, one of the founders of the group Comité marche du 23 mai 1998 (CM98-Committee for the March of 23 May 1998), later recalled: "that day, for the first time, the descendants of slaves remembered their enslaved forebears and were proud of them" (Rolle-Romana 2011, p. 85).

Exactly a decade on, a crowd gathered once more, this time outside the Basilica of Saint Denis in northern Paris, to watch the unveiling of nearly 400 panels containing the names of 25,857 ex-slaves from Guadeloupe and Martinique. The memorial, "les Noms de l'Abolition" (Abolition Names), was the result of three years' genealogical research by around 50 members of CM98. Each line of the memorial bore the first name and ID number of an Antillean ex-slave, along with the patronym s/he received just before abolition in 1848 - part of a huge administrative project by the French government to prepare its population of some 234,000 slaves for their imminent transformation into French citizens (Durand and Logossah 2002). In the words of Emmanuel Gordien, the leader of this genealogical project, assembling those names and presenting them publicly through the memorial served as a way of bringing their bearers "out of the anonymity of our hearts and consciences. These Relatives, survivors of a crime against humanity, can now be honored as they should be, and take their place in History, and us along with them" (Gordien 2013).

As Rolle-Romana and Gordien's statements suggest, until very recently France's history of slavery had long been shrouded in silence-even among those who directly descend from its survivors. Indeed, as historian Myriam Cottias (Cottias 1997) has suggested, forgetting slavery was the price to be paid by ex-slaves in return for their citizenship in 1848-a transaction that was sealed symbolically by the mass distribution of surnames: new identities, marking a hiatus with the past. Unlike in the United States, the abolition of slavery in France was not succeeded by policies of racial segregation. Yet nor were France's new citizens allowed to merge seamlessly into the national body. The prevalence of racist scientific doctrines well into the following century enabled racial stereotypes of Blacks (a categorization attributed to individuals with African physical features) to flourish, becoming interiorized by Antilleans of all shades (Fanon 1952). While this stigma may have been escaped by individuals with light skin (N'Diaye 2005, p. 99), many nonetheless inherited the distinctive patronyms given to their ancestors-names that, in some cases, seemed to have been chosen to mock or shame the original bearer, and that have continued to be a cause of teasing and humiliation for their descendants (Romaine 2006; Chanson 2008; see also Abel et al.).

Moreover, whereas in the US the imposition of a hereditary legal definition of Blackness—which could only be escaped by the socially costly strategy of "passing for White" (Kerr 2005)—ultimately resulted in the reappropriation of the racial label and an elaboration of a collective Black American identity, in France the same thing did not occur. In the wake of World War II, the 1958 Constitution of the Fifth French Republic ushered in a new national spirit of anti-racism by assuring "the equality before the law of all citizens without distinction of origin, race, or religion." While this period did herald the decline of biological racism, both in France and abroad, the constitutional outlawing of political convergences around concepts of race or origin also made it difficult for minorities to articulate collective identities similar to those that were rallying in the United States in the 1970s. Indeed, these kinds of collective movement have been regarded with misapprehension by observers on both ends of the political spectrum in France, who view "communitarianism" as a potential challenge 
to French national unity (Dhume-Sonzogni 2007). Thus, it was not until the 1990s, amidst a profusion of commemorations of landmark anniversaries from the history of colonialism that were taking part throughout the Caribbean and the Americas, that a collective consciousness centering around an urge to remember slavery arose in France (Chivallon 2010).

According to Rolle-Romana, who is a psychologist by profession, the idea of channeling this impulse through genealogical research was conceived first of all among the leaders of CM98 as a way to help Antilleans to understand and come to terms with the non-conventional family forms that have shaped many of their backgrounds-structures that originated in slavery (see Mulot 2013). As she wrote in an academic article entitled "From Memory without Remembering to Raising Awareness and the Act of Naming":

[B]reaks in the line of descent have existed for a very long time for many of us [ ... ]. Some [of us] don't know our fathers. These are lineages with " $X$ "s, paternal lineages that no longer exist, men that weren't able to name their children, and so on. Since this schema is fairly classic among Antillean families, it is not obvious to us that these slaves are our ancestors. (Rolle-Romana 2011, p. 87)

Thus, when in a public meeting Gordien presented the results of his own research with his father, through which they had managed to uncover the "first slave in their family," Rolle-Romana remembers that the group felt "blown away. A young man fell to pieces: he has no father, he has no grandfather, but he has just found a slave ancestor, a real man with a name and a history" (Rolle-Romana 2011, p. 89). Through their subsequent genealogy project, CM98 created not only the Abolition Names memorial, but also a free online database where individuals can search for the origins of their own surnames and find the name and ID number of their most recent enslaved ancestor. ${ }^{12}$

The terms employed by Rolle-Romana to discuss the symbolic and emotional impact of uncovering the identity of a slave ancestor are strikingly similar to those used by DNA ancestry test-takers in the US, such as Jarreau and LeVar Burton, to talk about being linked genetically to an African ethnic group. In both cases, the new information is construed as forming a new origin or "root" for the individual's family tree, stabilizing the latter's own self-narrative by providing what Rolle-Romana calls "a matrix of meaning that explains our ways of functioning and our dysfunctionalities," and revealing "the nucleus of our identity" (Rolle-Romana 2011, p. 88). Yet, the location of this point of origin differs: as discussed above, for many American DNA test-takers it is to be found outside the US, in a culture and place that lie beyond the traumatic history of slavery. For the members of CM98, on the other hand, the trauma of slavery is their point of origin. As Rolle-Romana goes on to note in her article, the project has gone some way towards helping revert the stigma surrounding slavery, using workshops, public seminars and radio programs to encourage Antilleans to identify openly and proudly with their enslaved ancestors-an idea that until recently would have been unimaginable. For instance, she mentions her astonishment at hearing Antillean women phoning in to a genealogy talk show, hosted by a member of CM98 and aired on the DOM-TOM radio channel Tropiques FM, to learn the names of their enslaved ancestors. In Rolle-Romana's words:

When José Grard [ ... ] says "Yes, we've found your name," their excitement is perceptible and they ask: "Can I have their ID number?" Hearing this dialogue I think, "I must be dreaming!" How is it that Antilleans who absolutely don't want to hear about the history of slavery are calling up on the radio to ask for their ancestor's ID number? (Rolle-Romana 2011, p. 89)

The sale of DNA ancestry tests is currently prohibited in France, where personalized genetic analyses (such as paternity tests, medical screenings, or forensic analyses) may only be administered

12 See http:/ / www.anchoukaj.org/ (accessed on 19 January 2018). 
on the orders of a judge or doctor (Morant 2011). ${ }^{13}$ Yet, when asked hypothetically during a conference in Paris whether CM98 was interested in the idea of using genetic tests as a means of finding their African origins, prior to slavery, Gordien was dismissive of the notion. He explained that the concept behind the association's genealogy project was first and foremost to invert the stigma of slavery among Antilleans by giving them tools to be able to cultivate a feeling of pride in their enslaved ancestors, restoring to the latter a sense of humanity by retrieving their names, and therefore uncovering the starting point of their inherited family identities. Furthermore, Gordien pointed out that by identifying themselves as "slave-descendants," members of CM98 conceived of their own cultural origins as rooted firmly within the Americas. According to his argument, slave-descendants throughout the Americas had formed new, creole ethnic identities through the experience of slavery and, as such, there was nothing to be gained by using genetic tests to claim identities that ostensibly preceded that experience. Drawing a parallel with the case of slave-descendants in the United States, he asked, with a hint of irony: "Are African Americans not real Americans?"14

In the previous section, I suggested that the contemporary desire of African Americans to claim affiliations to African cultures outside the United States is intrinsically rooted in the broad ethnic turn of the 1960s and 70s, which paved the way towards the current multicultural, hyphenated model of identity. In the same way, the emphasis placed by CM98 on the historical conditions of slavery as the genesis-point of a shared Antillean identity can also be seen as influenced by the French national narrative of universalism and the aversion to ethnic distinctions that is contained within it. In my interactions with French and American scholars throughout this period of research, I frequently encountered the antagonisms manifested by each side towards the other's conceptions of Blackness: for instance, African-American academics who spoke knowingly of Black French scholars being "brainwashed" by their national ideology of color-blindness; and French researchers who complained at Black American scholars' compulsion to "racialize everyone." Against the backdrop of this recurring dynamic, Gordien's rejection of genetic ancestry tests-technologies firmly grounded within the North American tradition of producing ethnic categories as a mode of self-identification-may also be seen as an attempt to position CM98's political vision against this internationally dominant paradigm, which has so often served as a model and inspiration for the identity strategies of other Black diasporic populations.

It should be noted, however, that CM98 is not the only association to attempt to articulate the voices of the descendants of the enslaved in France, and nor is their preferred collective label as "slave-descendants" the only such formulation to be used in the country. In contrast to Gordien's viewpoint, some do prefer labels such as afro-descendant and afro-français-inspired by the North American hyphenated-identity model, and highlighting an affirmed cultural or ethnic affiliation to Africa. Meanwhile, racial terms such as noir and black are also increasingly heard nowadays. While the former has been reappropriated in the last decade by intellectuals intending to use the label as a basis for a collective political identity (e.g., the Representative Council of Black Associations in France, CRAN), the latter is a loanword from American English, used primarily in youth slang to underline a sense of "disharmony" with the universalistic pretensions of France's national identity (Etoke 2009). Unlike the concept of "slave-descendants," these labels are not specific to Antilleans, but are also used by and for African migrants and their descendants, who share many similar experiences of discrimination-despite also being singled out for specific forms of stigmatization linked to their particular genealogies of colonization and racialization (Poiret 2011).

13 However, residents of France can —and a limited number do-get around this by ordering DNA ancestry tests online from foreign genetic-testing companies (Ducournau and Beaudevin 2011).

14 Author's notes from Q\&A session: "Genealogy, Identity and Genetics: Perspectives from African Descendant Organizations" (EUROTAST symposium: "Recasting Categories: Race, Ancestry, Belonging," held at the Alliance Française, Paris, 13 May 2013). 
Underlining all of these different usages, however, is a common preoccupation, described by Rolle-Romana as "our difficulty with living in France [ ... ] the fact that we do not feel completely French, that we find it hard to integrate into French society as citizens, even though we are French" (Rolle-Romana 2011, p. 89). In the following section, I will examine the case of Brazil, a country that has also experienced a recent upsurge in political activism, modeled primarily on North American strategies of identity politics and racial activism, and aimed at creating a collective Black identity in order to challenge widespread color prejudice and racial inequality. Like the United States, Brazil has a strong tradition of population genetic research-oriented in this case toward the outcomes of the nation's widely reputed history of racial mixture. Over the next pages, I will explore how this legacy has affected Black Brazilians' engagements with genetic testing, and their negotiation of the concept of "African descent," as a basis for constructing a cohesive racial identity.

\section{Blackness out of Mixture}

In 2000, a group of Brazilian geneticists published an article in the popular science magazine Ciência Hoje entitled "Retrato Molecular do Brasil"—A Molecular Portrait of Brazil. The piece was based on the results of uniparental analyses, carried out using cohorts of White Brazilian men from different parts of the country, and the results showed that while most of the men had Y-Chr lineages originating in Europe, $60 \%$ of the mtDNA lineages studied were of Amerindian or African origin (Pena et al. 2000). Seven years later, the online news source BBC Brasil ran a feature entitled "Afro-Brazilian Roots," in which nine Black Brazilian celebrities were offered uniparental and admixture tests, to delve into their genetic ancestry. Among the headlines, one case in particular caught the attention of the wider media: that of the samba artist Neguinho da Beija-Flor, whose stage name translates roughly as "Little Black Guy"-owing perhaps to his rich, dark skin tone. While the artist's uniparental lineages were linked to parts of Africa, his admixture tests indicated $67.1 \%$ European genomic ancestry. The article dedicated to his results was given the title "Neguinho da Beija-Flor has more European than African genes" (Glycerio 2007a).

Brazil is a country that for decades has founded its national identity upon the concept of its cultural and racial mixture (mestiçagem or miscigenação in Portuguese)-a notion that seems to be borne out by the genetic data cited above. Yet, far from being a simple fact of Brazil's colonial past, the notion of mixture also forms the foundation of a powerful political narrative, built up by Brazilian elites in the 1930s with the intention of unifying the nation internally, while also projecting onto the international stage an image of a progressive country enjoying a uniquely harmonious state of race relations (Schwarcz 1996). Despite this confident self-portrait, meant to strike a contrast with the divisive policies of racial segregation being pursued in the United States, South Africa, and Germany at the time, Brazilian governors and intellectuals had long been concerned with how to manage the country's large ex-slave population, broadly diagnosed as socially backward and racially degenerate by anthropologists and medical scientists during the late nineteenth century (Skidmore 1974; Schwarcz 1993). Although such scientific views receded during the early twentieth century, negative stereotypes associated with African physical traits have endured since, compounded by —and ultimately reinforcing — entrenched structures of socioeconomic inequality that disproportionately affect dark-skinned Brazilians (e.g., Fernandes 1972; Hasenbalg 1979).

The existence of widespread covert color prejudice in Brazil, combined with the nation's universalist constitution and a strongly-held belief in the virtue of mestiçagem as a means of overcoming racial differences, has created a difficult environment for activists who believe that cultivating a collective Black identity is the best way to improve the situation of dark-skinned Brazilians. This idea emerged most forcefully in the 1970s, as members of diverse Black Brazilian associations and movements (movimentos negros) became increasingly inspired by the successes of the civil rights movement and the impact of the Black Power slogan in the United States. However, it was not until the 1980s, following the transition to democracy after the military dictatorship, that Black activists gained the opportunity to directly influence public policy—an opening that also led to increased discussions 
about how best to delineate a conception of Blackness that was not only politically viable, but would also attend to the psychological damage wrought by the longstanding stigma associated with the term.

As the anthropologist Oracy Nogueira (Nogueira 2006) pointed out, whereas the historical stigma associated with Blackness in the United States functioned primarily through the concept of "origin" (meaning that anyone with a known Black ancestor was classified as Black, even if they had no visible traits that were construed as African), in Brazil this stigma has been one of "mark," meaning that "African" physical features (primarily skin tone), but not ancestry, are what guide designations of Blackness. Furthermore, whereas US segregation policies were based on the idea that racial mixture would cause "Negro blood" to irremediably taint White lineages, early twentieth-century Brazilian scientists and governing elites came to believe the opposite: that racial mixing would allow the nation's White stock to gradually cleanse the population of its non-White elements (Stepan 1991, pp. 153-62). This ideology of Whitening (branqueamento or embranquecimento) has come to pervade society, leading Brazilians of all colors to embrace "White" somatic norms and European cultural forms, while disparaging appearances and behaviors associated with Blackness. Such ideas become internalized, so that people who display physical markers of Blackness employ strategies to disguise or alter these telltale traits, for instance shaving or straightening kinky hair, or choosing to refer to themselves as moreno, which holds the connotation of being suntanned, rather than preto or negro (Black) (Pinho 2009).

Many activists stress the need to lay bare the unconscious negative attitudes underpinned by Whitening, in order to allow Brazilians to "accept themselves" as Black. One approach has been to encourage individuals to consider their own family history and notice how certain lineages are obscured while others are emphasized. For example, Frei David Raimundo dos Santos, a Franciscan monk and leader of the non-governmental organization (NGO) Educafro, ${ }^{15}$ has described how he first recognized his own Blackness as a young novice, after an interaction with a senior monk at a training monastery in the early 1970s. The Brother had singled Frei David out in the canteen, asking him if he would like to participate in a commemoration to his enslaved ancestors. Deeply affronted, Frei David protested that he was not Black, but simply "a little sunburnt from the beach." The offense at being called negro in front of his colleagues was such that Frei David decided to quit the monastery, but before he could do so the Brother requested a private meeting, asking him to bring with him some photos of his parents. Looking at the images, the Brother exclaimed, "your father is Black!", before going on to explain the ideology of Whitening to him. In Frei David's words:

[T] hat began to awaken a strange thing in me: "Goodness me, my father is a Black guy, he never spoke about Black people to me." And I began to think it over, to think back to the past: "My father practically erased [ ... ] his family, his siblings, his parents." I mean, we all grew up without knowing his family. And he brought us as close as possible to my mother's family: White people. [ ... ] And so there I began to understand how it grew in us, in me and my siblings, the consciousness of the rejection of the racial issue. (Alberti and Pereira 2004, p. 7)

In this account, recognizing the presence of Black relatives within his family tree allowed Frei David to perceive the long-term impacts of the Whitening ideology by seeing how it had shaped his own sense of his origins, while also giving him the opportunity to recast his identity as an Afro-descendant (afrodescendente). As Frei David explained when we met in August 2013, he and other Black Brazilian militants began attempting to popularize this term in the 1970s, in an analogy with the North American term "Afro-American," which had come to replace "Negro" as the accepted collective identity label for American Blacks. ${ }^{16}$ Echoing similar debates on the topic within the United States (e.g., Bennett 1967), Brazilian militants considered that whereas negro (which had been

15 See http:/ / www.educafro.org.br/site/ (accessed on 19 January 2018).

16 Interview, 15 August 2013. 
used commonly by activists in the early twentieth century) was a slavery-imposed designation that connoted a lack of history, the term afrodescendente had more positive connotations, implying an enduring intergenerational connection to Africa, its cultures and diasporas. Moreover, the concept of "descent" made the category available to Brazilians who might otherwise be identified as White or pardo (mixed or colorless) based on their skin color, thus encouraging such individuals for the first time to "darken" themselves via their chosen identity, rather than Whitening.

Today, some of the work of cultivating a sense of connection with Brazil's African heritage has been passed on to educators, after the introduction of a 2003 law that made classes on Afro-Brazilian history and culture a mandatory part of school curriculums. Some teachers have attempted to use genealogical exercises to help children connect with the topic-although these efforts are often frustrated by a lack of oral folklore or genealogical traditions within Brazilian families. One teacher reported that most pupils in her class were unable to complete the task of drawing a family tree, since their parents "claimed not to know their family stories, how their ancestors lived, where they lived, how they established themselves and came to form a social group in the region. In other words, [ . . ] they never preserved their origin nor did they pass it on to their children" (Matos 2010, p. 21). As I observed during a visit to a high school in Bahia, whose community had recently been recognized as descendants of fugitive slaves (quilombolas), the solution opted for by many teachers has been to cultivate positive views of Africa by giving historical overviews of the continent's pre-colonial civilizations, presenting Brazil's "Afro" heritage as a blend of these cultures and ethnic traditions, rather than using individual family histories as a conduit for identity construction (e.g., Melo and Braga 2010).

Whereas in the United States the sense of Sankofa—of "looking back to move forward"-is readily accepted as popular wisdom, in Brazil the opposite is seen as true. During my research there from July to September 2013, people regularly explained to me that "everyone in Brazil is mixed," as if this was all one needed to, or indeed could, know about the past. Indeed, the success of the political myth of mestiçagem, based on Gilberto Freyre's (Freyre 1934) sociological account of Brazil's colonial period, was its ability to offer a positive narrative of this history that would allow Brazilians to turn their gaze away from the past and towards their future as a modern, unified nation (Ortiz 2011, p. 42). At other times, the desire to mark a hiatus with the past has led to more destructive measures. For instance, two years after the abolition of slavery in 1888, the Minister of Finance, Rui Barbosa de Oliveira, ordered the mass burning of nineteenth-century fiscal documents relating to the ownership of Brazilian slaves, in a bid to thwart potential indemnification claims by landowners. Although a number of non-fiscal archives survived (e.g., church records of slave baptisms and marriages; judicial archives relating to criminal processes and wills), most have not been digitized, and genealogical studies of enslaved families remain the domain of professional historians rather than members of the public. In general, the main practitioners of genealogy in Brazil are descendants of old Portuguese noble families, or of colonists from other parts of Europe (Woortmann 1994).

And what of genetic testing? One of the main public projects to use DNA analyses to examine the origins of Black Brazilians was the abovementioned Afro-Brazilian Roots feature, published by $B B C$ Brasil in 2007. Although the piece was intended to celebrate Brazil's African heritage, in commemoration of the bicentennial of the abolition of the British slave trade, it ultimately became shrouded in controversy. This was mainly thanks to its publication at the height of an ongoing national debate about the introduction of "racial" quotas to federal universities, a public policy that was backed by many of the country's Black militant organizations, but which attracted virulent criticism due to its supporters' inability to settle on a workable political definition of Blackness to designate the recipients of the quotas, among other issues. ${ }^{17}$

The participants' results, published over the course of a week in May, provided ripe political fodder for voices on both sides of the polemic. A dedicated discussion forum on the BBC website

17 For a comprehensive overview of the "racial" quotas debates in Brazil, see Igreja (2009). 
offered a spread of public reactions to the feature: among the results that received the most direct responses in the forum were those of musicians Sandra de Sá and Seu Jorge, who were roundly criticized by readers, respectively, for affirming pride at "being nearly $100 \%$ African" and regret at not being genetically " $100 \%$ Black." These statements were described variously as "signs of intolerance" and "reverse racism" by commenters identifying themselves as "100\% Mongrel" and "a mixed-race Brazilian of planet Earth."18 Neguinho da Beija-Flor's results, meanwhile, were seized upon by members of the right-wing press to profess the absurdity of using race as a basis for allocating political resources in a country as genetically mixed as Brazil, and to underline what they saw as the "neo-racist" nature of the country's Black identity movements (e.g., Azevedo 2007). Conversely, Frei David, who also participated in the project, threatened to sue Sérgio Danilo Pena, the geneticist who processed the DNA analyses, claiming that the latter was using his scientific work to delegitimize the affirmative-action programs. Frei David, who stated at the time that he had participated in the project "precisely to polemicize it" (Ramos 2007), expressed his discontent about his own genetic results, which showed both his Y-Chr and mtDNA lineages to be of Amerindian origin. He explained: "I feel very frustrated with the work, given that the aim of the project was to investigate African origins [ ... ]. [Pena] simply boycotted the result on purpose" (Glycerio 2007c). ${ }^{19}$

Although unique among the BBC Brasil cohort, Frei David's genetic result is not necessarily unusual. For instance, in 2016 the Brazilian production studio Cine Group released a documentary called Brasil: DNA África, in which 250 self-identified Afro-Brazilians from five regions of the country had their mtDNA analyzed using tests provided by the US-based company African Ancestry. Carlos Alberto Jr., the show's director, told me that although the purpose of the documentary was to use the DNA tests to highlight Brazil's genetic links to different parts of Africa, numerous participants were found to have European or Amerindian, rather than African, mtDNA lineages. While most were accepting of their results, a few requested to have their Y-Chr analyzed in the hope of still being attributed a link to a particular country or ethnic group in Africa. Alberto Jr. recalled one participant in particular-a devout follower of the Afro-Brazilian religion Candomblé, who had visited several African countries-who was "devastated" to be informed that his mtDNA was of Amerindian origin and his Y-Chr of European origin.

More significantly, though, Frei David's animosity towards Pena was likely fueled by an earlier article that the geneticist had published, entitled Can genetics define who should benefit from university quotas and other affirmative actions? In it, Pena and co-author Maria Cátira Bortolini drew upon results from the earlier Molecular Portrait of Brazil study to argue that, extrapolating from the genetic data they extracted from groups of White Brazilian men, around $87 \%$ of Brazil's population could be considered afrodescendente, despite nearly half of this number currently identifying as White, according to census data-as well as many self-identifying Blacks carrying "a significant proportion of European ancestry" (Pena and Bortolini 2004, p. 46). Pena himself was a prominent voice throughout the quotas polemic, and was asked to provide an expert opinion on the matter during the 2010 Supreme Court hearing to determine the constitutionality of the university quota initiatives as a whole (Kent et al. 2014, p. 5). His unequivocal position was that genetic ancestry data could not help define who was Black in Brazil—an endeavor he said would amount to "a new racism" (Leite 2002). Pena's positioning of the concept of ancestry as inherently contradictory to the mission of creating a Black collective identity was regarded by Frei David as an effort to subvert the political usefulness of the notion of African descent, based on the very aspect that originally made it appealing as a resistance identity: the fact that as a description it rang true to most Brazilians, regardless of their skin color.

18 “Você acha que o conceito de raça ainda faz sentido no Brasil?" BBC News Forum, 28 May 2007. Available online: http:/ / newsforums.bbc.co.uk/ws/thread.jspa?sortBy=1\&forumID=3129\&start=435\&tstart=0\#paginator (accessed on 8 August 2014).

19 For a more detailed discussion of the Afro-Brazilian Roots project, and of the altercation between Frei David and Sérgio Danilo Pena, see Neto and Santos (2011). 
For militants in Brazil, then, connecting with an African origin, or mobilizing the concept of African descent as a basis for a collective identity are projects that, while deemed desirable by some, remain politically sensitive. Since the quotas debates, and the polemical reactions generated by the Afro-Brazilian Roots project, Black activists have become particularly wary of DNA admixture tests, whose results risk underlining the salience of the myth of mestiçagem that their movement seeks to critique and undermine. This marks a stark difference with the United States, where the logic of the "one-drop rule" has been successfully recuperated by African Americans to ensure the continuing salience of Blackness as a resistance identity, based on both biological ancestry and a transmitted cultural heritage- a definition that is rarely questioned in the US context. Thus, when Henry Louis Gates, Jr. was attributed 50\% European genomic ancestry in the first series of African American Lives, he was able to joke: "Fifty per cent European, I never expected that! I mean, do I still qualify for Affirmative Action? Can I get a reparations check? Half a reparations check? I had the blues. Can I still have the blues?!" (Judd and Farrell 2006). In contrast, when I asked the activist Flávio Carlos Nogueira, a colleague of Frei David's at Educafro, whether he would ever consider taking a DNA ancestry test, his attitude was much more ambivalent:

We have to think about that information so that it is used for the good of the community. We have to think really hard about what it's going to be used for. Depending on how the information is used, yes, I might take [a genetic test], if it was used in such a way that we could not generalize everything according to genetics. Because what discriminates, what humiliates, what hurts, what keeps our people out of spaces of circulation, what forms an opinion of you-it's phenotype, not genotype. ${ }^{20}$

\section{Conclusions}

The three cases outlined in this paper serve as examples of some of the different ways in which concepts of ancestry, descent and origin have been used to underline narratives of identity among Black populations in contemporary post-slavery societies. In the United States, Alex Haley's Roots myth has recently been reinvigorated for a new generation, with the proposition of genetic testing as a novel and scientific tool for claiming an African homeland and ethnic identity, in order to symbolically revert the trauma of slavery and the Middle Passage. Meanwhile, the digitization of records and expansion of the online genealogy market in general has also nourished traditional forms of family history research, allowing practitioners to tend to a much broader spectrum of roots within the US. In France, where the politicization of ethnic distinctions is widely seen as subversive, some activists have mobilized the notion of slave descent by using genealogies of names to draw attention to a long-silenced aspect of France's colonial history, while simultaneously situating their own collective origin and cultural heritage firmly within the French Antilles. Finally in Brazil, in the apparent absence of genealogical traditions and materials upon which to build Black family histories, militants have looked for alternative ways to build and shore up a shared "Afro-descendant" identity, which seems constantly under threat of being subsumed by the dominant national myth of mestiçagem.

As these examples demonstrate, origins are deeply political. Likewise, genetics and genealogy are not merely tools for unearthing stories that lay hidden; rather, they are the means by which individuals and groups construct narratives of ancestry, a process that inevitably involves prioritizing some lineages while ignoring others, as well as privileging a particular site of ethnogenesis over other possible origins (Nash 2008, p. 16). The cases discussed above suggest that public perceptions about where African-descendants should look for their origins are shaped by various overarching sources of influence, notably: national narratives that are bound up with ideologies of race, anti-racism, and conceptions of citizenship; discourses of scientists and experts regarding genetic and genealogical knowledge; and projects of activists, aimed at fostering community healing, race consciousness and

20 Interview, 15 August 2013. 
political protest. Moreover, as root-seeking practices are increasingly technologized, there emerge new debates over the authenticity and legitimacy of genetic vs. traditional sources of historical knowledge, in which those who manage to position themselves in public as the translators and custodians of genetic data are often given precedence in terms of dictating and shaping how these tools may or may not be read, interpreted, used. As indicated by the experiences of some African-American genealogists, this can lead to internal tensions if genetic data become privileged over other sources of family history knowledge, or if one narrow conception of roots comes to displace more variegated notions of origin.

In light of the cultural differences outlined in this article, to what extent can Sankofa be seen as a fitting metaphor for the diaspora as a whole? Anthropologist Pauline Guedj has described how the concept came to prominence among African-American activists during the 1960s and 70s as a result of sustained exchanges with Ghanaian cultural and political collectives. The Akan symbol became an emblem for these visionaries, who believed that quests for African ancestry and a return to origins (identified specifically with Kwame Nkrumah's pan-Africanist Republic of Ghana) could provide the solution to the "Black problem" at home in the US (Guedj 2011, p. 9). In the intervening decades, the symbol's ascribed meanings in the United States have broadened beyond this Ghanaian-North American connection, signifying an urge to "go back and fetch" personal histories and origins, more often than a collective past. As we have seen, this idea is thoroughly coherent with the United States' multicultural model of identity; the widespread contemporary commodification of ethnic heritage (Comaroff and Comaroff 2009); and a voracious consumption of ancestry (genetic and otherwise).

In France, meanwhile, the efforts of the group CM98 to "go back" and retrieve the names and ID numbers of their enslaved ancestors have been used to visibilize the lives and identities of those African-descendant individuals-while also drawing attention to the continuing sense of alienation and not-quite-belonging felt by some Antilleans in French society. Nonetheless, the pioneers of this approach have previously rejected what they regard as a North American focus on claiming African ethnicities as a vector for recuperating individual pasts, instead concentrating on their shared collective experience of slavery within the Antilles. Indeed, in both France and Brazil, activist groups and movements have been more concerned with building collective identities founded in common historical trajectories or shared experiences of discrimination than with searching for individual ethnic origins that could further factionalize these movements. In the Brazilian context in particular, attempts to focus on individual roots using DNA ancestry tests have had the effect of magnifying the internal fragility of these categories. Following BBC Brasil's Afro-Brazilian Roots project, for instance, several of the test-takers' results were held up by critics to highlight the "inauthenticity" or inadmissibility of a collective Black political identity in a society where the ideology of national unity through mixture is so deep-rooted. The apparently irreconcilable contradiction that these genetic data presented even to some self-identifying Black Brazilians was summed up by musician Seu Jorge, who affirmed: "I was really hoping to be $100 \%$ Black. If I was, I would have asked for a really heavy indemnification from this country, but I'm also a descendant of the perpetrators" (Glycerio 2007b).

Nevertheless, the patterns and practices I have outlined above are by no means fixed; rather, they are shifting processes that respond to changing political situations, emerging struggles, developing technologies, and evolving networks of knowledge. For example, since the conference at which he spoke in Paris in 2013, Emmanuel Gordien (now president of CM98) has embarked upon a project to trace one of his family lineages back to West Africa. In 2016, he released a documentary film based on this journey, entitled Citoyens bois d'ébène (Ebony Citizens), which showed Gordien visiting a community in south-east Benin who share the same family name, Bouriqui, as one of his enslaved ancestors (Salin 2016). In an interview about his experience, Gordien stated that he believed it was now time to think of fostering a type of "memory tourism" between the French Antilles and West Africa, "even if I don't like the term." Regarding his personal reactions to the trip, Gordien described himself as feeling "full of Africa," despite knowing that he is "not African" (Gbadamassi 2016). It remains to 
be seen whether the association will now begin to shift its focus towards helping other Antilleans trace their family lineages back to Africa.

Similarly, since the cooling of the quotas debates, some Brazilians have made subsequent attempts to use DNA ancestry tests to explore Brazil's diverse ancestral connections with Africa. One such project was the aforementioned Brasil: DNA África documentary, which followed roughly the same format as African American Lives, although with a greater emphasis on tracing African cultural survivals in Brazil than individual family histories. In one episode, the Bahian architect Zulu Araújo, a former director of the Palmares Cultural Foundation, ${ }^{21}$ traveled to Bankim in Cameroon, where he was officially recognized by King Gah II Ibrahim as a "member of the Tikar family," based on his DNA result. In a voice-over, however, Araújo reaffirmed his Brazilian identity, stating that he felt the Cameroonians he met there knew he was "not African," and suggesting that the important thing was not to "live looking backwards," but rather work on constructing the future (Monteiro 2015). Nevertheless, in an interview given at the time of the documentary's release in 2016, Araújo reiterated the personal importance of having made a connection with a place of origin in Africa: "The journey completed me as a citizen. If anyone asks me where I'm from, I know now what to respond. Only someone who is Black can understand the enormity of what that means" (Fellet 2016).

Gaining a personal sense of connection with a point of origin beyond slavery can clearly foster strong feelings of catharsis and empowerment. Yet for the main part, genetic ancestry data gain their symbolic interpretations and political power from the local contexts in which they are produced, notably by intersecting with the myths of race and national identity that have shaped concepts of origin and Blackness there. As such, the primacy and appeal of DNA ancestry tests that reproduce a particular North American model of identity, prizing the recuperation of "ethnic" labels as a means of symbolically "reversing the Middle Passage," should not be taken as universal, nor should this paradigm be placed above alternative ways of thinking and commemorating slave-descent that have developed out of different historical, cultural, and political contexts. Neither should DNA "ethnicity" analyses be regarded as the only tool that genetics can contribute towards researching the lives and identities of enslaved Africans-as emerging studies from other Atlantic contexts are beginning to show (e.g., Callaway 2016; Jagadeesan et al. 2018; Pálsson 2016, pp. 228-29). Based on her study of the US setting, Alondra Nelson has pointed out that "DNA can offer an avenue toward recognition, but cannot stand in for reconciliation" (Nelson 2016, p. 164). Yet, as I have argued using the examples explored above, it should not be taken for granted that DNA ancestry tests will turn out to be a useful tool for gaining political recognition—let alone social justice—for Black populations everywhere.

Acknowledgments: The author would like to thank Myriam Cottias, Gísli Pálsson, and the three anonymous reviewers for their valuable feedback and helpful suggestions during the preparation of this manuscript. This work was completed thanks to support from the CitiGen project (2016-2019), which has received funding from the European Union's Horizon 2020 research and innovation program under grant agreement No. 649307. The initial fieldwork for this study was completed within the framework of the EUROTAST project (2012-2015), a Marie Curie Actions Initial Training Network, funded by the European Union under the Seventh Framework Programme (FP7/2007-2013, grant no. 290344).

Conflicts of Interest: The author declares no conflicts of interest. The author holds a current, non-remunerated affiliation with the DNA-testing company Living DNA in the capacity of Academic Advisor; however, the company had no role in the design of this study; in the collection, analyses, or interpretation of data; in the writing of the manuscript, or in the decision to publish the results.

21 The Fundação Cultural Palmares, linked to the Ministry of Culture, focuses on the promotion and preservation of Black culture in Brazil. 


\section{References}

Abel, Sarah. 2016. A la recherche des identités transatlantiques. Des boucles conceptuelles au croisement de la société, l'histoire et la génétique. Nuevo Mundo Mundos Nuevos. Colloques. October. Available online: http:/ / nuevomundo.revues.org/ 69589 (accessed on 25 February 2018).

Abel, Sarah, George F. Tyson, and Gísli Pálsson. Forthcoming. Naming and Slavery: The Middle Passage and Beyond. Comparative Studies in Society and History.

Abu El-Haj, Nadia. 2012. The Genealogical Science: The Search for Jewish Origins and the Politics of Epistemology. Chicago and London: University of Chicago Press.

Alberti, Verena, and Amilcar Araujo Pereira. 2004. História do Movimento Negro no Brasil: Constituição de acervo de entrevistas de história oral. In Identidade negra e reconhecimento. Fortaleza: Universidade Federal do Maranhão, São Luís, Available online: http:/ /cpdoc.fgv.br/producao_intelectual/arq/1412.pdf (accessed on 25 February 2018).

Anderson, Benedict. 1991. Imagined Communities: Reflections on the Origins and Spread of Nationalism. London: Verso.

Azevedo, Reinaldo. 2007. A farsa neo-racista do Brasil em três momentos. Veja. May 30. Available online: http:/ / veja.abril.com.br/blog/reinaldo/geral/farsa-neo-racista-brasil-em-tres-momentos/ (accessed on 19 January 2018).

Benn Torres, Jada. 2014. Prospecting the Past: Genetic Perspectives on the Extinction and Survival of Indigenous Peoples of the Caribbean. New Genetics and Society 33: 21-41. [CrossRef]

Bennett, Lerone, Jr. 1967. What's In a Name? Negro vs. Afro-American vs. Black. Ebony 23: 46-54.

Bolnick, Deborah A., Duana Fullwiley, Troy Duster, Richard S. Cooper, Joan H. Fujimura, Jonathan Kahn, Jay S. Kaufman, Jonathan Marks, Ann Morning, Alondra Nelson, and et al. 2007. The Science and Business of Genetic Ancestry Testing. Science 318: 399-400. [CrossRef] [PubMed]

Brodwin, Paul. 2002. Genetics, Identity, and the Anthropology of Essentialism. Anthropological Quarterly 75: 323-30. [CrossRef]

Brodwin, Paul. 2005. "Bioethics in Action" and Human Population Genetics Research. Culture, Medicine and Psychiatry 29: 145-78. [CrossRef] [PubMed]

Byrnes, Jake. 2013. Synthesizing Genetic and Genealogical Data to Elucidate African American Ancestry. Paper presented at The African Diaspora: Integrating Culture, Genomics and History, National Museum of Natural History, Smithsonian Institution, Washington, DC, USA, September 12; Available online: https: / / www.youtube.com/watch?v=Q2GKukY9jIU (accessed on 25 February 2018).

Callaway, Ewen. 2016. Freedom in Exile. Nature 540: 184-87. [CrossRef]

Chanson, Philippe. 2008. La blessure du nom. Une anthropologie d'une séquelle de l'esclavage aux Antilles-Guyane. Louvain-la-Neuve: Bruylant-Academia.

Chivallon, Christine. 2010. Mémoire de l'esclavage et actualisation des rapport sociaux. In Les traites et les esclavages: Perspectives historiques et contemporaines. Edited by Cottias, Myriam, Elisabeth Cunin and António de Almeida Mendes. Paris: Karthala, CIRESC, pp. 335-56.

Chivallon, Christine. 2014. Revisiter l'ancestralité aux Antilles. Usages anciens et nouveaux de nomination des ancêtres à la Martinique. Civilisations 63: 101-22. [CrossRef]

Comaroff, John L., and Jean Comaroff. 2009. Ethnicity, Inc.. Chicago \& London: University of Chicago Press.

Cottias, Myriam. 1997. L'oubli du passé contre la citoyenneté; Troc et ressentiment à la Martinique (1848-1946). In 1946-1996 Cinquante ans de départementalisation outre-mer. Edited by Constant, Fred and Justin Daniel. Paris: L'Harmattan, pp. 293-313.

Dhume-Sonzogni, Fabrice. 2007. Liberté, égalité, communauté? L'Etat français contre le "communautarisme". Paris: Homnisphères.

Du Bois, William Edward Burghardt, Elijah Anderson, and Isabel Eaton. 1996. The Philadelphia Negro. Philadelphia: University of Pennsylvania Press, First published 1899.

Ducournau, Pascal, and Claire Beaudevin. 2011. Génétique en ligne: déterritorialisation des régulations de santé publique et formes de développement commercial. Anthropologie E Santé 3. Available online: http: / / anthropologiesante.revues.org/777 (accessed on 25 February 2018).

Durand, Guillaume, and Kinvi Logossah. 2002. Les noms de famille d'origine africaine de la population martiniquaise d'ascendance servile. Paris: L'Harmattan. 
Ely, Bert, Jamie Lee Wilson, Fatimah Jackson, and Bruce A. Jackson. 2006. African-American Mitochondrial DNAs often Match MtDNAs Found in Multiple African Ethnic Groups. BMC Biology 4: 1-14. [CrossRef] [PubMed]

Etoke, Nathalie. 2009. Black Blanc Beur: Ma France à moi. Nouvelles Études Francophones 24: 157-71.

Fanon, Frantz. 1952. Peau noire, masques blancs. Paris: Seuil.

Fellet, João. 2016. “Na África, indaguei rei da minha etnia por que nos venderam como escravos”. BBC Brasil. January 14. Available online: http:/ /www.bbc.com/portuguese/noticias/2016/01/160113_dna_africano_ zulu_jf_cc (accessed on 19 January 2018).

Fernandes, Florestan. 1972. O negro no mundo dos brancos. São Paulo: Difusão Européia do Livro.

Frazier, E. Franklin. 1939. The Negro Family in the United States. Chicago: University of Chicago Press.

Freyre, Gilberto. 1934. Casa-grande e senzala. Rio de Janeiro: Maia \& Schmidt.

Frye Jacobson, Matthew. 2006. Roots Too: White Ethnic Revival in Post-Civil Rights America. Cambridge and London: Harvard University Press.

Garrett, Christine. 2010. Genealogical Research, Ancestry.com, and Archives. Doctoral thesis, Auburn University, Auburn, AL, USA. Available online: http://etd.auburn.edu/bitstream/handle/10415/2014/Christine. Garrett_thesis.pdf?sequence=1\&isAllowed=y (accessed on 25 February 2018).

Gates, Henry Louis, Jr. 2009. In Search of Our Roots: How 19 Extraordinary African Americans Reclaimed Their Past. New York: Crown.

Gbadamassi, Falila. 2016. “Citoyens bois d'ébène": Sur les traces de leurs aïeux africains. France Info. October 29 sct. Géopolis. Available online: http:/ / geopolis.francetvinfo.fr/citoyens-bois-d-ebene-sur-les-traces-deleurs-aieux-africains-123097 (accessed on 19 January 2018).

Geertz, Clifford. 2000. The Interpretation of Cultures, 2000 ed. New York: Basic Books, First published 1973.

Glycerio, Carolina. 2007a. Neguinho da Beija-Flor tem mais gene europeu que africano. Folha de S. Paulo. May 29. Available online: http:/ / www1.folha.uol.com.br/folha/bbc/ult272u300314.shtml (accessed on 19 January 2018).

Glycerio, Carolina. 2007b. "Se fosse 100\% negro, lutaria por indenização". BBC Brasil. May 30. Available online: http:/ / www.bbc.co.uk/portuguese/reporterbbc/story/2007/05/070409_dna_seujorge_cg.shtml (accessed on 25 February 2018).

Glycerio, Carolina. 2007c. 68\% africano, ativista queria mais detalhes. BBC Brasil. May 31. Available online: http:/ / www.bbc.co.uk/portuguese/reporterbbc/story /2007/05/070507_dna_freidavid_cg.shtml (accessed on 19 January 2018).

Gordien, Emmanuel. 2013. Les patronymes attribués aux anciens esclaves des colonies françaises. In Situ. February 20. Available online: https://journals.openedition.org/insitu/10129 (accessed on 25 February 2018).

Guedj, Pauline. 2009. Afrocentrismes américains: Histoire, nationalisme noir et pratiques sociales. Civilisations 58: 9-21. [CrossRef]

Guedj, Pauline. 2011. Panafricanisme, religion akan et dynamiques identitaires aux États-Unis. Le chemin du Sankofa. Paris: L'Harmattan.

Haley, Alex. 2007. Roots: The Enhanced Edition. The Saga of an American Family, Kindle ed. New York: Vanguard, First published 1976.

Hartman, Saidiya. 2007. Lose Your Mother: A Journey along the Atlantic Slave Route. New York: Farrar, Straus and Giroux.

Hasenbalg, Carlos. 1979. Discriminação e desigualdades raciais no Brasil. Rio de Janeiro: Graal.

Higham, John. 1975. Strangers in the Land: Patterns of American Nativism 1860-1925, 2nd ed. New York: Atheneum.

Igreja, Rebecca. 2009. El proyecto de cuotas raciales y la afirmación del negro en Brasil. Nuevo Mundo Mundos Nuevos. [CrossRef]

Jagadeesan, Anuradha, Ellen D. Gunnarsdóttir, S. Sunna Ebenesersdóttir, Valdis B. Guðmundsdóttir, Elisabet Linda Thordardottir, Margrét S. Einarsdóttir, Hákon Jónsson, Jean-Michel Dugoujon, Cesar Fortes-Lima, Florence Migot-Nabias, and et al. 2018. Reconstructing an African Haploid Genome from the 18th Century. Nature Genetics. [CrossRef] [PubMed]

Judd, Graham, and Leslie D. Farrell. 2006. Beyond the Middle Passage. African American Lives, Television documentary. Directed by Graham Judd. Arlington: PBS, February 8.

Kent, Michael, Ricardo Ventura Santos, and Peter Wade. 2014. Negotiating Imagined Genetic Communities: Unity and Diversity in Brazilian Science and Society. American Anthropologist 116: 1-13. [CrossRef] 
Kerr, Audrey Elisa. 2005. The Paper Bag Principle: Of the Myth and the Motion of Colorism. Journal of American Folklore 118: 271-89. [CrossRef]

La Roche, Cheryl J., and Michael L. Blakey. 1997. Seizing Intellectual Power: The Dialogue at the New York African Burial Ground. Historical Archaeology 31: 84-106. [CrossRef]

Leite, Marcelo. 2002. Raça é só conceito social, diz DNA brasileiro. Folha de S. Paulo. December 17 sct. Genética. Available online: http:/ / www1.folha.uol.com.br/fsp/ciencia/fe1712200201.htm (accessed on 25 February 2018).

Lynch, John. 2017. The 20 Most-Watched TV Episodes of All Time. Business Insider. October 1 sct. Tech. Available online: http:/ / www.businessinsider.com/most-watched-episodes-2016-9 (accessed on 19 January 2018).

Mack, Mark E., and Michael L. Blakey. 2004. The New York African Burial Ground Project: Past Biases, Current Dilemmas, and Future Research Opportunities. Society for Historical Archaeology 38: 10-17. [CrossRef]

Matos, Terezinha Solange Borges Silveira de. 2010. Resistências e desafios na abordagem escolar de temáticas da história africana e afro-brasileira numa experiência de estágio em pedagogia. Bachelor's thesis, Universidade Federal do Rio Grande do Sul, Porto Alegre, Brazil. Available online: http:/ / hdl.handle.net/10183/37734 (accessed on 25 February 2018).

McKay, Aprille Cooke. 2002. Genealogists and Records: Preservation, Advocacy, and Politics. Archival Issues 27: 23-33.

Melo, Elisabete, and Luciano Braga. 2010. História da África e afro-brasileira: Em busca de nossas origens. São Paulo: Selo Negro.

Mills, Gary B., and Elizabeth Shown Mills. 1981. "Roots" and the New "Faction": A Legitimate Tool for Clio? The Virginia Magazine of History and Biography 89: 3-26.

Mills, Elizabeth Shown, and Gary B. Mills. 1984. The Genealogist's Assessment of Alex Haley's Roots. National Genealogical Society Quarterly 72: 35-49.

Monteiro, Monica. 2015. Bahia. Brasil: DNA África, Television documentary. Directed by Carlos Alberto Jr.. Brasilia: Cine Group.

Morant, Guillaume de. 2011. Loi bioéthique révisée: Rien de nouveau sous le soleil généalogique. La Revue Française de Généalogie. October 10. Available online: http://www.rfgenealogie.com/sinformer/infos/nouveautes/loi-bioethique-revisee-rien-de-nouveau-sous-le-soleil-genealogique (accessed on 19 January 2018).

Moulton, Kristen. 1999. Mormon Church Web Site "Real Boon to Genealogy". The Atlanta Journal-Constitution, May 24, A3.

Moynihan, Daniel Patrick. 1965. The Negro Family: The Case for National Action; Report; Washington: United States Department of Labor.

Mulot, Stéphanie. 2013. La matrifocalité caribéenne n'est pas un mirage créole. L'Homme 207-8: 159-91. [CrossRef]

N’Diaye, Pap. 2005. Pour une histoire des populations noires en France: Préalables théoriques. Le Mouvement Social 213: 91-108. [CrossRef]

Nash, Catherine. 2008. Of Irish Descent: Origin Stories, Genealogy, E the Politics of Belonging. New York: Syracuse University Press.

Nelson, Alondra. 2008a. Genetic Genealogy Testing and the Pursuit of African Ancestry. Social Studies of Science 38: 759-83. [CrossRef] [PubMed]

Nelson, Alondra. 2008b. The Factness of Diaspora: The Social Sources of Genetic Genealogy. In Revisiting Race in a Genomic Age. Edited by Koenig, Barbara A., Sandra Soo-Jin Lee and Sarah S. Richardson. New Jersey: Rutgers University Press, pp. 253-68.

Nelson, Alondra. 2016. The Social Life of DNA: Race, Reparations, and Reconciliation after the Genome. Boston: Beacon.

Neto, Verlan Valle Gaspar, and Ricardo Ventura Santos. 2011. Biorrevelações: Testes de ancestralidade genética em perspectiva antropológica comparada. Horizontes Antropológicos 17: 227-55. [CrossRef]

Nogueira, Oracy. 2006. Preconceito racial de marca e preconceito racial de origem: Sugestão de um quadro de referência para a interpretação do material sobre relações raciais no Brasil. Tempo Social 19: 287-308, First published 1954. [CrossRef]

Novak, Michael. 1973. The Rise of the Unmeltable Ethnics, Paperback ed. New York: Macmillan, First published 1971.

Oduah, Chika S. 2009. The DNA Debate: Can It Help Black Chicagoans Find African Relatives? Medill Reports Chicago. December 1. Available online: http:/ / newsarchive.medill.northwestern.edu/chicago/news.aspx? id=150565 (accessed on 25 February 2018). 
Ortiz, Renato. 2011. Cultura brasileira e identidade nacional, 5th ed.São Paulo: Brasiliense.

Palmié, Stephan. 2007. Genomics, Divination, “Racecraft". American Ethnologist 34: 205-22.

Pálsson, Gísli. 2012. Decode Me! Anthropology and Personal Genomics. Current Anthropology 53: S185-95.

Pálsson, Gísli. 2016. The Man Who Stole Himself: The Slave Odyssey of Hans Jonathan. Translated by Anna Yates. Chicago and London: University of Chicago Press.

Panofsky, Aaron, and Joan Donovan. 2017. When Genetics Challenges a Racist's Identity: Genetic Ancestry Testing among White Nationalists (Pre-Print). SocArXiv. August. Available online: https:/ / osf.io/preprints/ socarxiv /7f9bc (accessed on 25 February 2018).

Pena, Sérgio D. J., and Maria Cátira Bortolini. 2004. Pode a genética definir quem deve se beneficiar das cotas universitárias e demais ações afirmativas? Estudos Avançados 18: 31-50. [CrossRef]

Pena, Sérgio D. J., Denise R. Carvalho-Silva, Juliana Alves-Silva, and Vânia Ferreira Prado. 2000. Retrato Molecular do Brasil. Ciência Hoje 27: 16-25.

Pinho, Patricia de Santana. 2009. White but Not Quite: Tones and Overtones of Whiteness in Brazil. Small Axe 29: 39-56. [CrossRef]

Poiret, Christian. 2011. Les processus d'ethnicisation et de raci(ali)sation dans la France contemporaine: Africains, Ultramarins et "Noirs". Revue Européenne des Migrations Internationales 27: 107-27. [CrossRef]

Ramos, Cleidiana. 2007. Pesquisa da BBC é apontada como estratégia contra cotas. A Tarde, June 24, sct. Salvador e região metropolitana. 11 .

Roberts, Dorothy. 2011. Fatal Invention: How Science, Politics, and Big Business Re-Create Race in the Twenty-First Century. New York and London: The New Press.

Rolle-Romana, Viviane. 2011. De la mémoire sans souvenir à la prise de conscience et à l'acte de nommer. Migrations Société 6: 85-92. [CrossRef]

Romaine, Alain. 2006. Les noms de la honte. Stigmates de l'esclavage à l'île Maurice. Port Louis: Marye-Pike.

Rotimi, Charles N. 2003. Genetic Ancestry Tracing and the African Identity: A Double-Edged Sword? The American Journal of Human Genetics 86: 661-73. [CrossRef]

Rushdy, Ashraf H. A. 2001. Remembering Generations: Race and Family in Contemporary African American Fiction. Chapel Hill and London: University of North Carolina Press.

Salin, Franck. 2016. Citoyens bois d'ébène, Documentary film; Paris: Beau Comme une Image.

Santos, Ricardo Ventura, and Marcos Chor Maio. 2005. Anthropology, Race, and the Dilemmas of Identity in the Age of Genomics. História, Ciências, Saúde-Manguinhos 12: 1-22.

Schramm, Katharina. 2010. African Homecoming: Pan-African Ideology and Contested Heritage. Walnut Creek: Left Coast Press, Inc.

Schramm, Katharina. 2012. Ancestry, Heritage and the Politics of Identity across the Black Atlantic. In Identity Politics and the New Genetics: Re/Creating Categories of Difference and Belonging. Edited by Schramm, Katharina, David Skinner and Richard Rottenburg. New York and Oxford: Berghahn, pp. 167-92.

Schwarcz, Lilia K. Moritz. 1993. O espetáculo das raças: Cientistas, instituições e questão racial no Brasil 1870-1930. São Paulo: Companhia das Letras.

Schwarcz, Lilia K. Moritz. 1996. Usos e abusos da mestiçagem e da raça no Brasil: Uma história das teorias raciais em finais do século XIX. Afro-Ásia 18: 77-101.

Scully, Mark, Steven D. Brown, and Turi King. 2016. Becoming a Viking: DNA Testing, Genetic Ancestry and Placeholder Identity. Ethnic and Racial Studies 39: 162-80. [CrossRef]

Skidmore, Thomas E. 1974. Black into White: Race and Nationality in Brazilian Thought. New York: Oxford University Press.

Sommer, Marianne. 2012. “Do You Have Celtic, Jewish or Germanic Roots?” Applied Swiss History before and after DNA. In Identity Politics and the New Genetics: Re/Creating Categories of Difference and Belonging. Edited by Schramm, Katharina, David Skinner and Richard Rottenburg. New York and Oxford: Berghahn, pp. 116-40.

Stepan, Nancy Leys. 1991. The Hour of Eugenics: Race, Gender, and Nation in Latin America. Ithaca and London: Cornell University Press.

TallBear, Kim. 2003. DNA, Blood, and Racializing the Tribe. Wicazo SA Review 18: 81-107. [CrossRef]

TallBear, Kim. 2013. Native American DNA: Tribal Belonging and the False Promise of Genetic Science. Minneapolis: University of Minnesota Press.

Tamarkin, Noah. 2014. Genetic Diaspora: Producing Knowledge of Genes and Jews in Rural South Africa. Cultural Anthropology 29: 552-74. [CrossRef] 
Weil, François. 2013. Family Trees: A History of Genealogy in America. Cambridge and London: Harvard University Press.

Winstein, Keith J. 2007. Harvard's Gates Refines Genetic-Ancestry Searches for Blacks. The Wall Street Journal. November 15. Available online: http://www.wsj.com/articles/SB119509026198193566 (accessed on 19 January 2018).

Winston, Cynthia E., and Rick A. Kittles. 2005. Psychological and Ethical Issues Related to Identity and Inferring Ancestry of African Americans. In Biological Anthropology and Ethics: From Repatriation to Genetic Identity. Edited by Turner, Trudy R. Albany: State University of New York, pp. 209-29.

Woortmann, Ellen F. 1994. A árvore da memória. Anuário Antropológico 92: 113-31.

Wright, Donald R. 1981. Uprooting Kunta Kinte: On the Perils of Relying on Encyclopedic Informants. History in Africa 8: 205-17. [CrossRef]

(c) 2018 by the author. Licensee MDPI, Basel, Switzerland. This article is an open access article distributed under the terms and conditions of the Creative Commons Attribution (CC BY) license (http://creativecommons.org/licenses/by/4.0/). 